\title{
THE DIVERSITY IN THE CRITICAL ESSAY GENRE IN WESTERN UKRAINIAN PERIODICALS OF 1920 - 1930s
}

\author{
Наталія КУЧМА \\ Кандидат філологічних наук, доцент, \\ Тернопільський національний педагогічний університет \\ імені Володимира Гнатюка, Україна \\ e-mail: nati7@ukr.net

\section{Галина ДЕРКАЧ} \\ Кандидат філологічних наук \\ Тернопільський національний педагогічний університет \\ імені Володимира Гнатюка, Україна \\ e-mail:halder@tnpu.edu.ua \\ https://orcid.org/0000-0003-0923-2134
}

DOI 10.25128/2304-1222.20.51.02

\section{ABSTRACT}

The paper deals with genre varieties of a literary critical essay (reviews, feature articles, essays, portraits, series of essays), which functioned in the periodicals of Western Ukraine in the 20-1930s of the XX century. The authors have shown how, through the interpenetration of components of different genres of literary criticism, basic style features of the leading critics of the denoted time and region, primarily Ye. - Yu. Pelenskyi, M. Rudnytskyi, M. Kovalskyi, L. Nyhrytskyi, S. Hordynskyi - were formed. Specific examples demonstrate the dominant criteria for critical assessments and perceptions.
\end{abstract}

Key words: literary criticism, genre, literary portrait, review, preface, peer review, cycle, essay.

Стаття стосується жанрових різновидів літературно-критичного есе (рецензії, фейлетони, нариси, портрети, серії есе), що функціонував у періодичних виданнях Західної України у 20-30-ті роки XX століття. Автори показали, як завдяки взаємопроникненню компонентів різних жанрів літературної критики сформувалися основні стилістичні особливості творів провідних критиків зазначеного часу та регіону, особливо Є.Ю.Пеленського, М. Рудницького, М. Ковальського, Л. Нигрицького та С. Гординського. Домінуючі критерії критичних оцінок та спостережень показані на конкретних прикладах.

Ключові слова: літературна критика, жанр, літературний портрет, рецензія, передмова, рецензія, серія, есе.

Artykuł dotyczy odmian gatunkowych literackiego eseju krytycznego (recenzje, felietony, eseje, portrety, cykle esejów), które funkcjonowały w periodykach zachodniej Ukrainy w latach 20. i 30. XX wieku. Autorzy pokazali, jak poprzez przenikanie się składników różnych gatunków krytyki literackiej ukształtowały się podstawowe cechy stylistyczne prac czołowych krytyków wskazanego czasu i regionu, przede wszystkim J. -J. Pelenskiego, M. Rudnyckiego, M. Kovalskiego, L. Nyhryckiego i S. Hordynskiego. Dominujące kryteria krytycznych ocen i spostrzeżeń zostały pokazane na konkretnych przykładach.

Słowa kluczowe: krytyka literacka, gatunek, portret literacki, recenzja, przedmowa, recenzja, cykl, esej.

In Western Ukrainian criticism of the said period, we often find speeches in which the literary process and the tendencies of its development are dealt with a particular period of time. Such reviews are not just about their creative victories and losses, for, say, a year (essays by O. Babiy "Literaturni zhyrnaly v 1922-1923 r." (Literary journals in 1922-23s)"; L. Burachynska "Na hrani roku" (At the Edge of the Year), "Nasha povist u 1937" (Our Novel in 1937), but also significantly longer time frames (for example K.K. "Literaturne zhyttia v Sovitskiy Ukraini" (Literary life in Soviet Ukraine). The 14 Studia methodologica, ISSN 2304-1222, No. 51. 2020 
publication “Suchasne zakhidno-ukrains'ke pys'menstvo. Ohliad za 1930-1935 roky” (Survey of Contemporary Western Ukrainian Literature, 1930-1935) by Ye. - Yu. Pelenskyi is considered the best example of such a review essay, aimed at showing the full palette of literary success over a long period of time. The author reconstructs the overall picture of the literary process of that time, highlighting traditions and innovation, explaining the advantages and dominants of NeoRomanticism and Neoclassicism on the one hand, and the influence of social aspects on literature on the other one.

Considering the successes of fiction, Ye.-Yu. Pelenskyi dwells separately on lyrics (in more detail on famous names, mentioning young and promising; 41 names in all), "epics", paying special attention to prose and journalism (30 names), drama, which he considers “за найслабше місце в сучасній нашій поезії' (the weakest point in our modern poetry) (7 names). The critic does not analyse the pros and cons of these works, limiting himself to some very precise value judgments and statements of facts. For example, “Від популярних, з перестарілою технікою драм, яких у нас багато, відбивають інтересні спроби Меріяма (Г. Лужницького). В своїх двох оперетках зумів він поєднати модерні засоби із цікавим сюжетом і добрим комізмом”. 3 молодших драматургів можна назвати Галана (“Вантаж”), І. Крушельницького (“На скелях”) і Б.Гомзина (“Кров кличе”, 1933). Оглядач звертає увагу читачів на мистецькі експерименти: “Досить рідкий у нас жанр новелі з еротичним сюжетом, легкого французького типу, започаткував “Нагодами й пригодами” М. Рудницький. Куди далі пішов Степан Левинський (“3 японського дому”, 1933, “Схід і Захід”, 1934). Він покидає Мопасанівську легкість, щоби піти слідом КупрінаАрцибашева. Еротизм стає тут яскравий, заслонює все проче” [Пеленський 1935: 45-46]. (interesting attempts by Meriyam (H. Luzhnytskyi) differ from numerous popular dramas with outdated techniques we have many. In his two operettas, he managed to combine modern means with an interesting plot and a good comedy. Among younger generation of playwrights Halan ("Cargo"), I. Krushelnytskyi ("On the Rocks") and B. Homzyn ("Blood Calls", 1933) could be mentioned. The observer draws the readers' attention to experiments in art: "M. Rudnytskyi was the first to suggest a rather rare in our country genre of short story with an erotic plot and of a light French type ("Possibilities and Adventures"). Stepan Levinskyi went even farther ("From the Japanese House", 1933, “East and West”, 1934). He leaves Maupassant's lightness to follow in the footsteps of KuprinArtsibashev. Eroticism here becomes vivid, overshadowing everything else)

Offering an example of Stepan Tudor's experimental quest (“Moloshne Bozhevillia”, 1930), Pelenskyi emphasizes: “Позитивне тут хіба намагання до мелодійности мови. Засіб простий i один: накопичення слів, де є звук “літ” [...]. Робили це вже багато раніше і то багато краще футуристи Семенко і Шкурупій [Пеленський 1935: 47-48]. (The only positive thing here is the desire for melodious language. The means is simple and the only one: piling up words with the sound "lit".... This was done much earlier and much better by the futurists Semenko and Shkurupiy) The 
reference to the experience of the writers of Naddnipryanshchyna (the Dnieper Ukraine) is not accidental. The critic, when reviewing the literature of Western Ukraine of 1930-1935s, constantly tries to put it into the all-Ukrainian context, and in a certain way, also into the European one. Pelenskyi's review, both in its meaning, structure, level of generalizations, and accuracy of evaluation can be referred to a succinct monograph. Therefore, the genre modification can be defined as an essay-monograph of a review character.

On the pages of Halychyna periodicals the following forms of reviews are featured: one author's works review (I. Fedorenko “Oscar Wilde (Review of Literary Works)” [ЛНВ 1923: 339345], review of the works of a group of authors (Ye. Malanyuk "U susida. Dekilka profiliv suchasnyh polskyh poetiv". (At the Neighbours. Some Profiles of Modern Polish Poets)”. [Мамай 1923: 47-50]

S. Hordynskyi published an interesting combination of a recension and review on the pages of "Nazustrich" ("Назустріч"): "Chotyry retorty liryky", dedicated to the poetry of B.-I. Antonych (“Try persteni”), N. Levytska-Kholodna ("Vohon' i popil”), Yu. Kosach ("Cherelen") and Ye. Malaniuk (“Zemna Madonna”). The critic clearly outlined his intent: “Пишучи тепер про поезію, не буду чіплятися поодиноких віршів, буду говорити про поетів, як герольдів своїх ідеалів, буду говорити “виясняльно”, щоб якнайбільш об’єктивно з'ясувати кожного поета, як вислів власного типу” [Назустріч 1935: 2]. (I am writing about poetry now, I will not cling to individual poems, I will talk about poets as heralds of their ideals, I will speak "explanatorily" in order to define each poet most objectively as a phrase of his own type). But he prefaced it with general reflections on the fact that contemporary literature “потопає... в патріотично-популярних писаннях" (is sinking... in patriotically-popular writings), which he considered a trouble. Such poetry makes sense if their patriotic moments “зростуться органічно в один емоційний комплекс 3 мистецькою формою" [ibid] (merge organically into an emotional complex with the form of art) Further he warned against using “порівняльного методу з іншими, чужинними поезіями” (the comparative method with other, foreign poetry). It is on this basis that the critic formulates his clear and precise judgments, presents the readers' impressions, and shares his doubts and raptures.

The reviews presented on the pages of Western Ukrainian editions were mostly in line with the canons of the genre and were structured by the authors' desire to examine the development of certain trends in the literary process within a clear chronological framework against a social, and historical-literary background.

Among the genre diversity of the critical essay, a special place was given to discussion speeches. It is in this that the situational and discursive nature of literary criticism, which for all its vivid individual features still remains a collective affair, was expressively manifested. Truth manifests itself in confrontation. Disputes, discussions, polemics, regardless of their sharpness and passion, remain a necessary condition of the normal literary process, conditioned by the nature of the artistic world. 
More often than not, such clashes, provoked by individual writers and critics, concerned questions of ideology. In such cases, each critic behaved in a peculiar way. Thus, S. Hordynskyi wrote mainly polemical essays. M. Rudnytskyi wrote essays, D. Dontsov preferred op-eds or "fiery speeches", and O. Turianskyi liked open letters or reviews. The topic of the sharpest polemics was self-criticism in its newspaper-journal stream functioning. Briefly, the priorities of such criticism can be conveyed in the words of S. Hordynskyi: "Передусім критика: маємо на увазі не ту, що іiі роблять професори і що зветься науковою. Вона нам мало цікава й для сучасности, яка нас передусім захоплює, неістотна. Ми їі заперечуємо в літературі, бо нема індивідуалістичної науки, а літературна критика знає лише індивідуальності, людей і твори, а втім, живемо в часі, коли свобода мистецтва і його вічне відновлювання, вічна змінність $є$ вже річчю, що не викликає сумнівів. Зате критика філософічна - оце рямки, в яких добре почувається сучасна література. Для цього не треба обов'язково бути філософом; [...] філософічна культура — це не знання систем, а здібність роз'єднувати інтелектуальні поняття й вічно розбивати застиглі системи на те, щоб туди впровадити ж и т т я. Такий підхід дає нам спроможність краще зрозуміти літературну творчість, бо першим обов'язком критика $є-$ все зрозуміти, не замикатися перед ніякою новою спробою й бути здібним сприймати навіть найтонкіші й найбільш непередбачені способи міркування" [Ми 1935: 150]. (First of all, criticism: we don't mean the kind that professors make and which is called scientific. It is of little interest to us and is not important for modernity, which we are primarily fascinated by. We deny it in literature, because there is no individualistic science, and literary criticism knows only individuals, people and works, and in general we live in the times when the freedom of art and its eternal revival, eternal changeability is already a thing that does not cause doubts. But philosophical criticism is the framework within which contemporary literature feels good. You don't have to be a philosopher to do this, [...] philosophical culture is not about knowledge of systems, but about the ability to disentangle intellectual concepts and to break down perpetually frozen systems in order to introduce life there. Such an approach gives us a better understanding of literary work, for the first duty of the critic is to understand everything, not to be closed before any new attempt, and to be able to perceive the subtlest and most unforeseen ways of thinking)

The approaches to the evaluation of a literary work as a thoroughly individual phenomenon were not shared by all, even by the representatives of liberal and aesthetic criticism. Whereas M. Rudnytskyi made high demands on the aesthetic form and psychology of characters, S. Dolenho believed that ideas and even political convictions, if they are organically woven into the fabric of a work of fiction, must necessarily be accentuated.

A group of young writers with a nationalist orientation presented their approaches to the evaluation of a work of art in the article "Criteria for Evaluating the Artistic Creation" written by 
S. Osynskyi. They argued "При розцінці вартости мистецького твору — треба б — для легшого перегляду перевести таке схематичне розмежування:

Естетичний момент;

Етична тенденція;

Національно-суспільна ідея твору” [Назустріч 1935: 3] (When evaluating a work of art, the following scheme should be applied: Aesthetic moment; Ethical tendency; National social idea of the work)

The most interesting is that by ethical moment, young people meant heroics. The rhetorical discourse unfolded in this way “...Чи можна оцінити позитивно твір з чужою нам чи протилежною національно-суспільною ідеєю? Чи для оцінки вартости твору є неодмінно доконечні стисло поєднані ті три засади, вище згадані? Вартість признаємо за таким твором, що у висліді у сприймача викликує героїчне етичне пережиття, що находить своє творче відношення до його національної ідеї, посереднє чи безпосереднє, - в психіці читача чи загалом сприймача. Значить, естетичний момент у зв'язку з героїчною концепцією життя продовжуваного у творі?!... Цей критерій може бути тільки тоді вальорний, коли ступінь естетичних пережить і життєвої ідеології сприймача є того роду, що ворожих нам суспільних ідей твору він не прийме, не здемобілізується ними, а естетичні й героїчні елементи твору посилять у ньому кохання його національно-суспільної ідеї...” [ibid] (Is it possible to evaluate positively a work of art with an idea that is foreign to us or opposite to the national-societal idea? Or, are all these three above-mentioned combined components necessary for work of art evaluation? We recognize as qualitative that work, which in consequence causes heroic ethical experience in the recipient, which directly or indirectly finds its creative ratio with the national idea in the psyche of the reader or the recipient in general. The aesthetic moment, then, in connection with the heroic conception of life continued in the work! ... This criterion can be weighty only when the degree of the aesthetic experiences and life ideology of the recipient is such that he will not accept the hostile social ideas of the work, and will not be demobilized by them, but the aesthetic and heroic elements of the work will strengthen his love to his national-social idea)

That is, we see that the dialogueness of evaluative judgments operates in the form of an internal monologue, addressed to a specific addressee (its potential reader) and at the same time influenced by the presence of ideological opponents, who will not read such a text. The educational and didactic function dominates in such speeches.

One of the most popular and mobile genres of literary criticism of the interwar twenties in Halychyna was the review. Such a critical speech had a clearly defined goal: to give Halychyna's readers an idea of the general state of Ukrainian literature and its individual phenomena, to determine their place in the historical and literary process, the territorial division of Ukraine, in the socio-cultural life of Halychyna. Very often, the logical structure of such approaches (especially in newspapers) 
consists of such components: a general assessment of current events (or some event) of literary life, free associative transitions from one phenomenon to another, strongly pronounced subjectivity. The speech by M. Kovalskyi "Memento vivere” (“Кілька слів про сучасну поезію”) (“A Few Words about Modern Poetry”) can be considered an example of such a review. The author, continuing D. Dontsov's thesis about the crisis of Ukrainian literature, considered emigrant poetry. He believed that the main motifs of these poems were disappointment, fatigue, exhaustion, hopelessness, and despair, confirming his conclusions with quotations from the works of A. Pavlyuk, M. Osyka, M. Obidnyi. Evaluation criteria for him were the works of famous writers of Ukraine, because the period of national revival still lasted, M. Kowalski stressed: “...i мусимо таки признати, що творчість тогобічна, себто на Вел.Україні, по зовнішній формі значно яскравіша, живіша. “Червоний Шлях” у кождому разі інтересніше читати, ніж “Нову Україну”. [ЛНВ 1924: 335] (We should confess, that the external form of literary creativity from that side, from Great Ukraine, is much brighter and vivid. "Chervonyi Shliah" is more interesting than "Nova Ukraina”) The reason that emigrant poetry has so far given nothing new, he saw in "самій психольогіï української індивідуальности, в степені національної свідомости" [ibid: 336]. (the very psychology of Ukrainian individuality, and in the degree of national consciousness) But the creative process on the other bank of the Zbruch River did not exactly appeal to the critic either. The lyrics of V. Yellan, Y. Savchenko and others seemed to him as “призмами, крізь які переломлюються російські тенденції” (prisms, through which Russian tendencies break). Comparing Ukrainian authors with S. Yesenin, M. Kovalskyi considers the latter not as a poet, but primarily as a Russian, moreover - a communist. The conclusions of the author of the essay were based mainly on his ethno-psychological ideas: “Причини анемічности творчости на еміграції і неприродности мистецьких шляхів на Україні полягають у тому, що в нас - Українців - іще не психольогія побідника, не визволеного Прометея, не вільного духом відродженого велетня, свідомого своєї сили, - але психольогія paбa" [ibid: 338]. (The reasons for the anemic nature of creativity in emigration and the unnaturalness of the paths of art in Ukraine is that we, Ukrainians, do not yet have the psychology of a winner, not a liberated Prometheus, not a free-spirited reborn giant who is aware of his power, but the psychology of a slave)

The model of spiritual slavery for M. Kovalskyi was then Pavlo Tychyna: Перші книжки Тичини - “Сонячні Кларнети” і “Плуг” - якраз показують визволеннє з-під духового рабства укр. індивідуальности. Далі - “Замісць сонетів і октав” - глибокий містицизм, біль по втраті, по незабутньому. А “В космічному оркестрі” се вже ясний поворот до старої психольогії раба, що тулиться до сильного “міра сего” [ibid: 339]. (Tychyna's first books "Soniachni klarnety” (The Solar Clarinets) and "Pluh" (The Plow) demonstrate the liberation of Ukrainian individuality from spiritual slavery. Then - "Zamist' sonetiv i oktav" (Instead of Sonnets and Octaves) - deep mysticism, 
pain of loss, about the unforgettable. And "V kosmichnomu orkestri" (In the Space Orchestra) is a clear return to the old psychology of a slave, who sticks to the strong 'of this world')

The critic addressed his predictions and wishes for the future not only to writers, but also to readers. “Інколи порівняти те, що створило мистецтво укр. на сьогоднішній день із тим, що могло воно створити і чого вимагає сучасна хвиля відродження нації - побачимо дуже мало плюсів, а багато витраченого надаремно часу, енергії й сил [...]. Хочеться вірити, - і на се маємо право - що діждемося того Мойсея, якого так болюче прагнув у “Плузі” Павло Тичина (не комуніст)" [ibid]. (Sometimes to compare the art which Ukr[aine] has created to date with what it could have created and what the modern wave of national revival requires - and we will see very little pluses and a lot of wasted time, energy and efforts [...]. We would like to believe, - and we have the right to believe - that we will wait for that Moses which Pavlo Tychyna (not a communist) so painfully waited for in his "Pluh")

Very often the purpose of such reviews was to represent to readers what they had not yet read. This is the most convenient form of performing the orientation and stimulating function. This type of reviews can include essays devoted to the literary process outside Ukraine (for example: Ye.M. (Ye. Malaniuk) “Z tvoriv "pershoi v sviti literatury”; M. Gnatyshak "Nova nimets'ka beletrystyka pro vijnu (richevi zamitki)”; M.R. (M. Rudnytsky) “Z novyh amerykans'ryh knyzhok”, etc.).

Preface and afterword were no less important types of critical essays. Such texts were not numerous, but popular. More often, they accompanied the works of European writers that were published in Lviv or as 'libraries'-supplements to magazines and newspapers. Very often such articles resembled sketches or essays, they preceded mainly Ukrainian translations of European writers, often little-known or, even, completely unknown to Halychyna's readers. Critics focused readers' attention on the winning points and successes of the writers, thus intending to demonstrate the creative portrait of the translated authors.

The preface "Romantychnyy siuzhet" (Romantic plot) to the book "Ivan Mazepa. Zhyttia i poryvy velykoho hetmana" (Ivan Mazepa. The Life and the Impulses of the Great Hetman), written by I. Borschak and R. Martel and published in Paris in 1931 can be considered a striking example of this type of critical texts. An authorized translation with a preface by M. Rudnytskyi was published in Lviv two years later. The critic, introducing a new book to the readers, explained the reasons and motives for its appearance. The preface consists of three parts, which one by one, present the impetus for the appearance of the biography of Mazepa. The critic explains how the book under consideration differs from those already written by other writers, and why the fictionalized study has become so popular in the world. M. Rudnytskyi, in his characteristic essayistic manner, pointed out: “Перекладаємо оту книжку тому, що у рідній мові не маємо досі кращої короткої монографії про Мазепу. Мета авторів познайомити чужину із одною сторінкою нашої бувальщини сходиться з потребою нашого загалу пригадати собі цю бувальщину” [Рудницький 1991: 7]. 
(We translate this book because we still do not have the best short monograph about Mazepa in our native language. The purpose of the authors - to acquaint foreigners with one page of our history coincides with the need of our society - to remember this history) The critic sees the reasons for this need as follows: “Остання війна зродила нову потребу оживляти легенди та відтворювати історичні події. Нервове покоління кінової доби має щораз менше часу та терпцю на товстелезні книги з причинками, коментарями, цитатами" [ibid: 5]. (The recent war has created a new need to revive legends and recreate historical events. The nervous generation of the cinema period has less and less time and patience for thick books with prefaces, commentaries and quotations) The critic believes that the war aroused the interest of wide readership in the lives of famous historical personalities not only in Ukraine. Demonstrating the process of developing of the genre of fictional biography in America, England, France, emphasizing the role of André Maurois in the self-affirmation of this genre, M. Rudnytskyi wrote: “Велика війна витворила голод геройства та історичних величин. Ї̈̈ непередбачена загальна невдача ще збільшила цю смагу. Мало коли в історії така велика війна $з$ такими великими гаслами зродила так мало індивідуальностей і відкрила людську підлоту в такій наготі. Небувале нинішнє зацікавлення життєписами давніх великих людей - це туга за величинами, за індивідуальностями" [ibid: 6-7]. (The Great War created a hunger for heroism and historical magnitude. Its unforeseen general failure further increased this need. Few times in history has such a great war with such great slogans given birth to so few individuals and so exposed human meanness. The unprecedented current interest in biographies of past great men is a mourning for the great, for individuals) The critic believed that the authors had escaped the danger of “робити із постатей нашої бувальщини самі крицеві статуї”, (creating only bronze statues from the figures of our history), to depict Mazepa - a man with all his advantages and disadvantages: “Мазепа при всій своїй інтелігенції не був таким програмовим героєм. Як справжній державний діяч і добрий дипломат ішов за потребами своєї доби, хитався, кидався на всі боки, був лисом, вовком і тільки людиною 3 пристрастями, себелюбством, упертістю та інколи надто великою вірою у свої сили” [ibid: 8]. (Mazepa, for all his intelligence, was not such a program hero. As a real statesman and a good diplomat, he followed the needs of his time, swayed, threw himself in all directions, was a fox, a wolf and only human, with passions, self-love, stubbornness and sometimes too strong faith in his own strength) The intonational and stylistic peculiarities of the critical narrative indicate that M. Rudnytskyi was impressed not only by Mazepa, "the most European among the Cossacks", but also by the authors of his biography, and most of all, by their attempt to show Ukraine not through boring political and historical journalism and "overly rural means". Borshak and Martel's Mazepa is not without his flaws. We can question more than one phrase, “передавану як ‘історичні слова' Мазепи, не один 'факт’, виведений на підставі документів та справоздання попередніх істориків. Діло не в тому, чи погоджуємося більше або менше з портретом Мазепи на тлі тодішньої доби, що ввижається нам завсіди як 
кожна історична доба крізь призму наших майбутніх ідеалів. Важне те, що автори не лякаються ясних, сміливих висновків, хоча не мають наміру йти за модним у слов'янських краях “патріотичним” навчанням історії” [ibid: 15]. (conveyed as Mazepa's "historical words”, or not a single "fact" given on the basis of documents and research of previous historians. It is not a question of whether we more or less agree with the portrait of Mazepa against the background of that time, which is seen from here as each historical epoch through the prism of our future ideals. It is important that the authors are not are not intimidated by clear, bold conclusions, although they do not intend to follow the fashionable in Slavic lands "patriotic" study of history) The important thing is that the authors are not intimidated by clear, bold conclusions, although they do not intend to follow the fashionable in Slavic lands "patriotic" study of history).

These examples from M. Rudnytskyi's essay show that S. Zalyhin was right, claiming that “передмова, якщо вона не ставить перед собою літературознавчого завдання, повинна лише доповнювати автора, повідомляючи читачеві щось таке, що напевно залишиться за рамками його творів - хай то будуть біографічні дані чи особисті враження від прочитаного” [Vis. Гром'як 1986: 20]. (a preface, if it not intended to be a literary criticism, should merely supplement the author by giving the reader something that is certain to remain outside the scope of his work, be it biographical data or personal impressions of what he has read) This also applies to the prefaces by S. Hordynskyi and O. Hrytsai, which preceded Ukrainian translations from French, Russian, German and English literatures (more than 20 publications of this type).

The desire for a holistic comprehension of literary and social life and the need for a rapid and at the same time regular response to current events and phenomena forced critics to turn to critical cycles. The peculiarity of such texts is the multi-genre nature of their components. The open structure of these cycles allows to write "mixes", freely moving from problem to problem. However, such a literary-critical cycle, for all its openness, is still a holistic creation, because it is characterized by conceptuality, a common systemic principle, a formal connection between the individual components, stylistic unity, unifying cross-cutting compositional details. An example of such a literary-critical discourse can be M. Rudnytskyi's cycle in the journal "Svit" (The World). During 1926-1929, the author published 19 literary-critical essays, in which he outlined various aspects of the psychology of creativity, reflected on the problems of adequate perception and full understanding of artistic works by contemporaries, relations between writers, and near-literary events. Much attention was paid to the author-reader-critic communication system, the contacts between writers and the press; also, he touched upon the moral and ethical aspects of literary creativity.

Mykhailo Rudnytskyi chose the most convenient genre, the essay, because it allowed him, on the one hand, to get as close to the reader as possible and create the illusion of a sincere conversation, and, on the other hand, to express his own views on the issues raised without the risk of being accused of authoritarian imposition of his opinion. On two occasions the critic used the genre of open-ended 
writing. In 1927 his speech "Who do you write for?" took the form of a speech, and in 1929 his letter to the young author of "Chy maju talant?" (Do I Have Talent) was presented in the form of a parting word.

A somewhat different structure had the critical cycles of K.K. and L. Nyhrytsky, published in the "Literary and Scientific Supplement to "Novyi Chas" (The New Time) in 1938. During the year, L. Nyhrytskyi (literary pseudonym of Hryhor Luzhnytskyi) published 14 essays in which he tried to explain to the readers what criticism is, its formation and development, and how he sees the modern literature. He used mainly the form of a literary-critical essay (8), a historical-literary essay (6), and one open letter. The author paid special attention to the period of the middle and second half of the 19th century, to such figures as Panteleimon Kulish ("Kulish-critic and Shevchenko", "P. Kulish on the Tasks of Ukrainian Criticism", "Between Kulish and Hrinchenko") and Borys Hrinchenko (Borys Hrinchenko's critique, Shadows of Hrinchenko-the-critic). It should be emphasized that while professing the principles of Catholic moral and ethical criticism, L. Nyhrytskyi thoroughly and objectively describes the state of criticism, the ways of its formation, emphasizes above all its educational nature and educational function in literature and society.

Critical cycle of K. K. on literary figures of the Dnieper Ukraine was published in the literary and scientific supplement to "Novy Chas" (The New Time) during 1938-1939, and consists of 15 articles. One of them is review-problematic ("Novorealism sovitskoi literatury" (New Realism of Soviet Literature)), and the rest are literary portraits, which migrate towards the historical-literary essay. These critic essays are primarily informative. The author outlines the ideological and thematic interests of each of the portrayed, names the works, determines their place in the literary process, emphasizing the detrimental effect of imperial ideology on writers, the collapse of talents, the formation of spiritual bifurcation.

To summarize, we can argue that the phrase "literary-critical essay" cannot have a strict terminological status, because it does not outline the semantic-structural formation and the nature of literary-critical activity. As a term it can name one of the types of criticism, that covers (summarizes) a number of clearly structured literary-critical genres (varieties of the genre).

\section{REFERENCES}

ЛНВ. 1923. Кн. V111. Т. 80 [LNV. 1923. Kn. VIII. T.80].

ЛНВ. 1924. Кн.111-1V [LNV. 1923. Kn.III-IV].

Мамай. 1923. Ч.1 [Mamai. 1923. Ch.1].

Ми. 1935. Кн.1V [Мy. 1935. Kn.1V].

Назустріч. 1935. Ч.2 [Nazustrich. 1935. Ch.2].

Пеленський, Є.-Ю. Сучасне західноукраїнське письменство. Огляд за 1930-1935 pp. Львів 1935 [Pelenskyi, Ye.-Yu. Suchasne zakhidnoukrainske pysmenstvo. Ohliad za 1930-1935 rr. Lviv 1935].

Рудницький, М. Романтичний сюжет. В: Ілько Борщак, Рене Мартель. Іван Мазепа. Життя і пориви великого гетьмана. Київ: Рад. письменник, 1991 [Rudnytskyi M. Romantychnyi siuzhet. V: Ilko Borshchak, Rene Martel. Ivan Mazepa. Zhyttia i poryvy velykoho hetmana. Kiyiv: Rad. pysmennyk, 1991].

Гром'як, Р.Т. Громадянськість і професіоналізм (Соціальна відповідальність критики): Літ.-крит. нарис. Київ: Рад. письменник, 1986 [Hromiak R.T. Hromadianskist i profesionalizm (Sotsialna vidpovidalnist krytyky): Lit.-kryt. narys. Kiyiv: Rad. pysmennyk, 1986]. 